\title{
Nutritional Composition of Three Selected Traditional Diets: A Case Study of Ngwa People in Abia State, Nigeria
}

\author{
Benjamin Acho Amadi, Lynda Nonye Eke, Mathew Owhonda Wegwu, Justice Obinna Osuoha* \\ Department of Biochemistry, University of Port Harcourt, Nigeria
}

Copyright $(2018$ by authors, all rights reserved. Authors agree that this article remains permanently open access under the terms of the Creative Commons Attribution License 4.0 International License

\begin{abstract}
The consumption and encouragement of indigenous diets could help alleviate malnutrition and mitigate food insecurity in developing countries. In this regard, three Nigerian traditional diets: Akidi (Vigna unguiculata), Akara-Igboro (manihot esculenta), and Ofe-achara (Pennisetum purpureum soup) mixed with Mgbam (baked melon seed) and Garri (Cassva flakes) were evaluated for sensory characteristics, proximate composition, anti-nutrient composition, as well as vitamins, and mineral content using standard methods. Data from the sensory characteristics indicated that Ofeachara mixed with Mgbam and Garri $(7.67 \pm 0.89)$ was the most acceptable diet. The proximate analysis also revealed that Ofeachara mixed with Mgbam and Garri was highest in carbohydrate, $(55.08 \pm 4.66 \%)$, Ash $(6.67 \pm 2.89 \%)$ and moisture content $(8.41 \pm 0.89 \%)$ while Akidi was highest in protein $(5.91 \pm 0.05 \%)$ and crude fibre $(12.31 \pm 0.01 \%)$. The anti-nutritional analysis of the diets revealed that Akara-Igboro had the highest phytate $(0.40 \pm 0.01 \%)$, Alkaloid $(50.00 \pm 1.33 \%)$, oxalate $(27.28 \pm 0.88 \%)$ and Cyanogenic glycosides content $(1.62 \pm 0.12 \%)$ when compared to other diets. The vitamin content also showed that Akara-Igboro had the highest concentrations of vitamin $\mathrm{B}_{2}$ and $\mathrm{C}(21.67 \pm 0.02 \mathrm{~g} / 100 \mathrm{~g}$ and $17.01 \pm$ $0.01 \mathrm{~g} / 100 \mathrm{~g}$ ) respectively. The highest level of calcium was found in Ofeachara mixed with Mgbam and Garri (0.08 \pm $0.01 \mathrm{mg} / 100 \mathrm{~g}$ ). This study revealed that these traditional diets are crucial sources of important nutrients. Increased consumption of these nutrient-rich diets will mitigate nutrition-related disorders.
\end{abstract}

Keywords Traditional Diets, Anti-nutrients, Nutritional Evaluation, Sensory Evaluation

\section{Introduction}

Food is any substance taken for the purpose of providing nutritional support for the human body. It could be of animal and/or plant origin, which have some indispensable nutrients, like minerals, proteins, fats and vitamin. When food is ingested and absorbed by the human body, its primary aim is to sustain life, provide energy and enhance growth and development. Food is apparently unavoidable as it is one of the basic requirements of life. It can also be regarded as any substance that promotes growth, produces energy etc. after undergoing metabolism in the body [1]. Careful selection of foods can provide all the essential nutrients that are needed for the proper functioning of the human body [2].

In most developing countries in the world, like in Nigeria, there is usually an acute shortage in terms of availability of food and its supply which could affect the nutritional status of the people in these countries. Unavailability or shortage of food and its supply is a serious challenge causing nutritional quagmire in Nigeria mostly amongst infants and mothers. This effect can lead to malnutrition, impaired growth and development of children and low efficiency levels amongst mothers.

Traditional foods are commonly referred to foods consumed locally by a particular community [3]. These foods contribute significantly to the diet of individuals living within and outside that county. Nutritional compositions of some traditional foods have been investigated in Nigeria $[4,5,6]$ and other countries $[7,8]$. However, various traditional foods consumed in Nigeria have not been evaluated.

Vigna unguiculata locally known as Akidi as well as Pennisetum purpureum locally known as Achara which is normally mixed with baked melon seed locally known as Mgbam to produce a soup called Ofe-Achara locally consumed with Cassava flakes Garri and Manihot esculenta cake locally known as Akara-igboro are prevalent traditional diets consumed by the Ngwa people of South Eastern part of Nigeria. The safety and nutritional composition of these diets are not known and have not been 
documented. Therefore, it is imperative to investigate the nutritional composition of these three selected traditional foods Akidi, Ofe-Achara and Akara-igboro commonly consumed by the Ngwa people of Nigeria in other to underscore the benefits, safety and possible risk associated with the consumption of the traditional diets.

\section{Materials and Methods}

\subsection{Traditional Foods Selection}

In this study, three traditional foods frequently consumed in Abia State, Nigeria were selected. The selection was based on data obtained from a pilot survey of eighty women living in Aba; a commercial city in Abia State. In accordance with the declaration of Helsinki, all participants signed a form of consent. Information on cooking procedures and ingredients were also obtained from the participants. This study was approved by the Nutrition and Toxicology Unit, Department of Biochemistry, University of Port Harcourt.

\subsubsection{Source of Samples}

The major raw ingredients and materials utilized in the preparation of the traditional foods used in the study were obtained from a local market known as Ahia Ohuru, in Aba, Abia State, Nigeria.

\subsubsection{Rationale for the Recipe in the Diet Preparation}

In order to work with the actual proportion of the condiments as would be prepared traditionally, the food stuffs for the preparation of the individual diet was weighed. The means of the weights for all the samples were compiled. Each diet was then prepared with these pre-determined preparations of the ingredients.

\subsection{Preparation of Ofe Achara Mixed with Mgbam and Garri}

This is a delicacy of the Abia people mostly the Ngwas. It is a local soup that is made from a vegetable known as Achara. Before the preparation of the soup, Baked Melon seed or Melon cake locally known as Mgbam was prepared. Three hundred grams of dehulled melon seed known as "Egusi" was placed in a wooden mortar alongside with $5 \mathrm{~g}$ of sliced onions and ground until a paste was formed, then $5 \mathrm{~g}$ of "Nsu", a thickener and $10 \mathrm{ml}$ of hot water was added. The "Nsu" helps the paste to be strong while the hot water helps in the extraction of oil from the melon. The melon paste was then molded into a desirable size using the hands. Then it was placed into $2000 \mathrm{ml}$ of boiling water in a cooking pot on a cooking gas and was allowed to boil for about 50mins under mild heat.
The soup was prepared by washing $300 \mathrm{~g}$ of red meat, $150 \mathrm{~g}$ of stockfish, $100 \mathrm{~g}$ of dried fish which was placed inside a cooking pot and was allowed to heat for about 10 mins on a gas cooker, after which $1 \mathrm{~g}$ of table salt, $50 \mathrm{~g}$ of crayfish, $10 \mathrm{~g}$ of fresh pepper and about $500 \mathrm{ml}$ of the water which was used to cook the baked melon seed was added and allowed to boil for about $30 \mathrm{mins}$, then $120 \mathrm{ml}$ of palm oil was introduced and allowed to boil for another 10mins. $10 \mathrm{~g}$ of "Ofor" (a soup thickener) was introduced to the combination and allowed to cook for 10mins and 500grams of the already peeled, washed and chopped "Achara" and the baked Egusi were added into the mixture and were allowed to heat for $3 \mathrm{mins}$ and the soup was ready.

One hundred grams of "Garri" was mixed with $50 \mathrm{ml}$ of hot water and turned homogenously in a bowl with a local stick until it becomes a paste. The "Garri" paste was used to serve the "Ofeachara mixed with mgbam" for a complete diet.

\subsection{Preparation of Akidi}

This is a special type of beans known as Cowpea (Vigna unguiculata) that is consumed amongst the Ngwa people, $90 \mathrm{~g}$ of sliced onions, $1 \mathrm{~g}$ of table salt, $500 \mathrm{ml}$ of water, $500 \mathrm{~g}$ of cowpea locally known as Akidi and $50 \mathrm{ml}$ of palm oil. The beans was sorted to remove dirt and debris and washed thoroughly. After which, it was introduced inside a cooking pot filled with $5000 \mathrm{ml}$ of water on a cooking gas and was allowed to boil for about 50mins. Ten grams of fresh pepper, $90 \mathrm{~g}$ of sliced onions was pulverized using a local pestle and mortar. After the cowpea was cooked until a paste-like product was formed, then $50 \mathrm{ml}$ of palm oil was added and was properly stirred. The ground $10 \mathrm{~g}$ of fresh pepper, $1 \mathrm{~g}$ of table salt and $90 \mathrm{~g}$ of sliced onions was also added and stirred thoroughly to get a homogenous mixture and was allowed to stand for five minutes.

\subsection{Preparation of Cassava cake Akara-igboro}

This is a delicacy made from cassava just like 'Beans Cake' but this could be called 'Cassava Cake' in English. $400 \mathrm{~g}$ of raw cassava was properly washed before and after peeling. A local grater was used to grate the cassava to a paste. After grating, a white cotton linen material was used to sieve out the water from the grated cassava. The cassava was then poured out into a bowl. Ten grams of fresh pepper, $50 \mathrm{~g}$ of crayfish, and $80 \mathrm{~g}$ of sliced onions were ground in a local mortar with pestle. Thirty milliliters of palm oil was added into the cassava residue in the bowl, and was mixed together, furthermore the ground mixture of fresh pepper and onions was added with $1 \mathrm{~g}$ of salt and was thoroughly mixed. The resulting mixture was then mould with hand into a desirable size and was deep fried into $250 \mathrm{ml}$ of palm oil. 


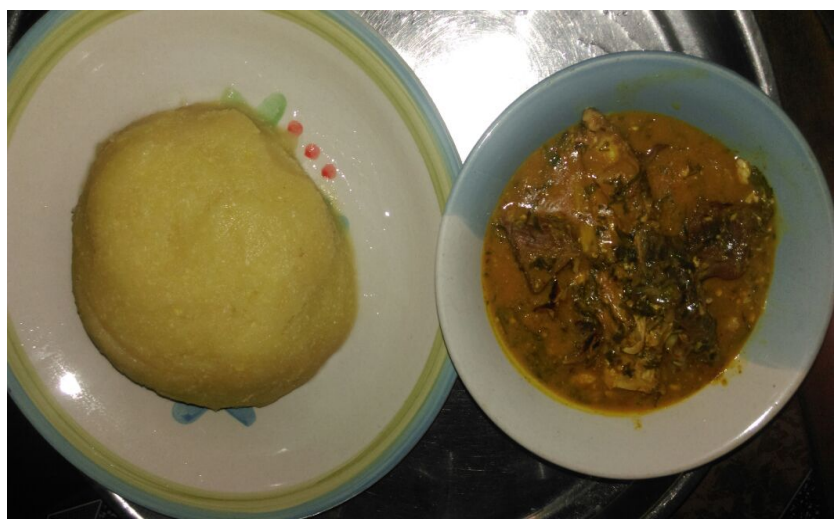

Figure 1. Garri and Ofe achara

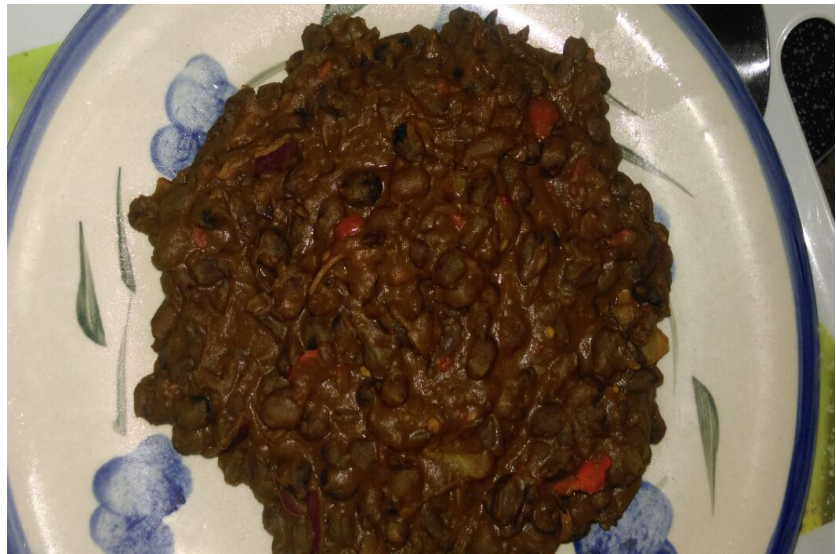

Figure 2. Akidi

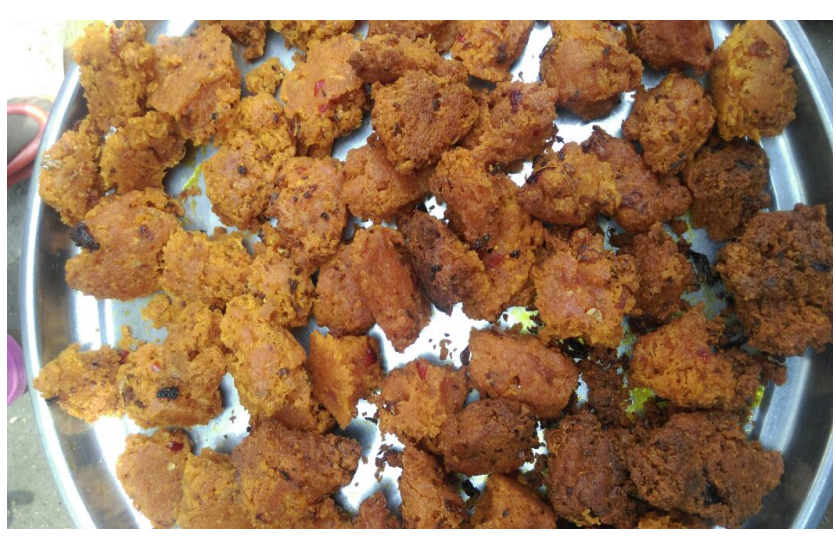

Figure 3. Akara-Igboro

\subsection{Preparation of Traditional Food Samples for Analysis}

The prepared traditional food samples were oven dried at $90^{\circ} \mathrm{C}$ for 2 hours. The oven dried specimen were ground into a pulverized form with a karasa blender and preserved in an air-tight sample container and transported to the laboratory for analysis.

\subsubsection{Sensory Evaluation}

The sensory evaluation of the food sample was carried out in the Nutrition and Toxicology Unit, Department of Biochemistry, University of Port Harcourt where the food was prepared. Ten non-teaching members of staff of University of Port Harcourt were randomly selected and trained. Each of the panelists was separated in different compartment and was served the freshly prepared "Akidi", "Ofe-Achara" and "Akara-igboro". The samples were evaluated for flavour, taste, colour, texture and overall acceptability by the Judges using a nine point hedonic scale, where 9 was the highest score and 1 the lowest. This was done in line with the technique described by Onwuka [9] and Amadi et al. [10].

\subsubsection{Determination of Proximate Composition}

Proximate analysis of the samples for crude fat, carbohydrate, ash, fiber, crude protein and moisture contents were determined using standard methods of AOAC [11].

\subsubsection{Determination of Anti-nutrient Composition}

The concentration of tannin was estimated using the Colourirnetric strategy of Folin Denis. The oxalate and phytate content was determined by the technique illustrated by [11]. Cyanogenic Glycosides content was dictated by basic pikrate colourimetric strategy [12]. Alkaloids were estimated by alkaline precipitation strategy as described by Harbone [13]. Saponin content was evaluated by the twofold dissolvable extraction technique [13].

\subsubsection{Determination of Vitamins}

The vitamin composition of the food was samples was analyzed using High Performance Liquid Chromatography (HPLC)

\subsubsection{Determination of Mineral Contents}

The minerals were analyzed collectively using an Atomic Absorbance Spectrophotomer (AAS).

\subsubsection{Statistical Analysis}

All samples were subjected to statistical analysis using SPSS version 20.

\section{Results and Discussion}

The result of the sensory evaluation of the traditional diets is presented in Table 1, notably the most acceptable food was Ofeachara mixed with Mgbam and Garri, followed by Akidi and Akara Igboro. The Proximate composition of the cooked food samples utilized in the preparation of traditional diets is presented in Table 2 while the results of the anti-nutrient levels are presented in Table 3 . The results of the vitamins and mineral levels of the traditional diets are presented in Table 4 and Table 5 respectively. 
Table 1. Sensory Evaluation of the Traditional Diets

\begin{tabular}{|c|c|c|c|}
\hline Sensory Attributes & Akidi & Ofeachara & Akara-Igboro \\
\hline Appearance & $6.67 \pm 0.87^{\mathrm{a}}$ & $7.22 \pm 1.09^{\mathrm{a}}$ & $5.89 \pm 1.7^{\mathrm{a}}$ \\
\hline Taste & $6.22 \pm 2.64^{\mathrm{a}}$ & $8.22 \pm 0.83^{\mathrm{b}}$ & $6.44 \pm 1.13^{\mathrm{a}}$ \\
\hline Aroma & $6.78 \pm 10.20^{\mathrm{a}}$ & $7.56 \pm 0.73^{\mathrm{a}}$ & $5.89 \pm 1.05^{\mathrm{a}}$ \\
\hline Colour & $7.00 \pm 1.00^{\mathrm{a}}$ & $7.22 \pm 0.67^{\mathrm{a}}$ & $6.11 \pm 1.27^{\mathrm{a}}$ \\
\hline Texture & $6.89 \pm 1.27^{\mathrm{a}}$ & $7.67 \pm 0.71^{\mathrm{a}}$ & $6.44 \pm 1.42^{\mathrm{a}}$ \\
\hline Overall acceptability & $7.11 \pm 1.16^{\mathrm{a}}$ & $7.67 \pm 0.87^{\mathrm{a}}$ & $6.11 \pm 1.16^{\mathrm{a}}$ \\
\hline
\end{tabular}

Values are presented as mean \pm S.D of ten panelists

Values bearing different superscript letters and found on the same row are significantly different

The rating by the sensory panel showed that the appearance, aroma, colour and texture did not affect the different traditional diets significantly except in Ofeachara mixed with mgbam and garri, where the taste varied from Akidi and Akara-Igboro.In the overall acceptability, Ofeachara mixed with Mgbam and Garri (7.67) was the most preferable to the panelists followed by Akidi (7.11), even though the decrease in the overall acceptability in Akara Igboro (6.11) was significant $(\mathrm{p}<0.05)$. The result was slightly different with the report of Ibanoglu [14] on Tarhana, a Turkish traditional food where commercial Tarhana was the most liked (8.20), although statistically no significant difference was observed in the general suitability between it and others.

Table 2. Proximate Composition (\%) of the Traditional Diets

\begin{tabular}{|c|c|c|c|}
\hline Constituents & Akidi & Ofeachara & Akara-Igboro \\
\hline Protein & $5.91 \pm 0.05^{\mathrm{c}}$ & $4.13 \pm 0.03^{\mathrm{b}}$ & $1.22 \pm 0.13^{\mathrm{a}}$ \\
\hline Crude fibre & $12.31 \pm 0.01^{\mathrm{c}}$ & $3.05 \pm 0.01^{\mathrm{a}}$ & $6.56 \pm 0.05^{\mathrm{b}}$ \\
\hline Carbohydrate & $45.18 \pm 1.83^{\mathrm{a}}$ & $55.08 \pm 4.66^{\mathrm{c}}$ & $50.77 \pm 4.66^{\mathrm{b}}$ \\
\hline Lipid & $18.00 \pm 2.00^{\mathrm{a}}$ & $22.00 \pm 2.00^{\mathrm{b}}$ & $38.02 \pm 2.00^{\mathrm{c}}$ \\
\hline Ash & $5.00 \pm 0.00^{\mathrm{a}}$ & $6.67 \pm 2.89^{\mathrm{a}}$ & $5.00 \pm 0.00^{\mathrm{a}}$ \\
\hline Acid value & $12.71 \pm 0.32^{\mathrm{a}}$ & $12.15 \pm 0.32^{\mathrm{a}}$ & $25.25 \pm 0.57^{\mathrm{b}}$ \\
\hline Moisture & $8.00 \pm 0.66^{\mathrm{b}}$ & $8.41 \pm 0.89^{\mathrm{b}}$ & $4.03 \pm 0.41^{\mathrm{a}}$ \\
\hline
\end{tabular}

Values are presented as mean \pm S.D of triplicate determinations. Values on the same row with different superscript letters differ significantly at $\mathrm{p} \leq 0.05$.

In the carbohydrate content of the cooked sample of the traditional food, Ofeachara mixed with Mgbam and Garri was the highest $(55.08 \%)$ followed by "Akara Igboro' $(50.77 \%)$ then Akidi (45.18\%). The variation observed in the carbohydrate content may not be unconnected to the type and quantity of ingredients utilized in the preparation of the foods. The explanation for the high carbohydrate content demonstrated in "Akara Igboro" could perhaps be credited to the basic component Cassava, which is a good source of energy since it is very rich in carbohydrate, while for that of "ofeachara" mixed with "Mgbam and Garri", the ingredient (garri) which is mixed with the diets after preparing the food is also known to be high in carbohydrate. The carbohydrate content of "Akara Igboro" (50.77\%) was comparable with the carbohydrate content of "Ntiti-Ikpa" $(50.45 \%)$ a traditional diet of the Ikwerre people in South-South Nigeria as reported by Amadi et al. [15]. Also the carbohydrate composition of "Akidi" (45.18\%) was comparable to that of "Khubez-Jabin" (44.20\%), a traditional food regularly devoured in the Arabian Gulf States [16]. A significant difference was found in the carbohydrate constituent of the three diets.

The protein content of the traditional foods was highest in Akidi (5.91\%) and lowest in Akara Igboro (1.22\%). The high protein content in Akidi could be attributed to the basic ingredient Cowpea, While that of Ofeachara mixed with Mgbam and Garri could be attributed to the protein content ingredient stocked fish, red meat and crayfish used in the preparation of the traditional diet. The protein content of "Akara-Igboro" (1.22\%) was low when compared to "Ekpan Nkukwo" (grated cocoyam and dried shrimps, $13.69 \%$ ), as reported by Umoh [17]. A significant difference was also observed in the protein composition of the samples. The elevated protein content in Akidi connotes that it can contribute to the daily protein requirements for children, adults and patients already suffering from protein deficiency disorders and diseases [18].

Lipid content of the cooked samples of the traditional food was highest in Akara Igboro (38.00\%) followed by Ofeachara mixed with Mgbam and Garri (22.00\%).Crude fibre content was high in "Akidi" (12.32\%), followed by Akara-Igboro (6.56\%) and lowest in Ofeachara mixed with Mgbam and Garri (3.05\%). These values compared well with those of other traditional foods like "Kantong" 9.70\% [19], sweet potato leaf soup- 5.88\% [20] and "Bhat Kerela Bhaji”, a traditional recipe of Assam, India- 12.6\% [21]. There was a significant difference in crude fibre composition of the diets. Since high crude fiber can improve digestibility, it also plays a vital role in the management and prevention certain disease conditions like cancer, diabetes, obesity and gastrointestinal disorders [22]. There is also a scientific proof that dietary fibre is helpful in the treatment of preset diabetes since it improves blood glucose tolerance [23].

The highest value for moisture contents of the cooked sample was Ofeachara mixed with Mgbam and Garri $(8.41 \%)$ followed by Akidi $(8.00 \%)$ and Akara-Igboro $(4.03 \%)$. However, the moisture contents of all the traditional food samples were low compared to that of katong (32.47\%) [19]. The high moisture content observed in some of the samples proposes that during storage the samples may be susceptible to bacterial spoilage. Elevated moisture content in a food sample has been implicated in microbial growth. Furthermore, the ash content of the traditional foods was high in Ofeachara mixed with Mgbam and Garri (6.67\%) which indicates that Ofeachara mixed with Mgbam and Garri has the highest measure of 
total mineral content which is a good nutritional attribution. This might be due to the ingredients crayfish and stockfish. The ash content of all the foods were more than $3.0 \%$ for that reason, they have nutritional relevance because [21] demonstrated leaves possessing ash content of $3 \%$ and above is ideal and recommended for food for humans. Melon has been reported to be rich in ash [18, 24].The ash content of all the traditional diet studied were high compared to those of some traditional recipes of Assam, India [21] and some traditional dishes from Ikwerre in South Nigeria [15].

The acid value content was high in Akara Igboro (25.25\%) followed by Akidi (12.71\%) the lowest was in ofeachara mixed with Mgbam and Garri (12.15\%). The acid value helps to measure or check for the degree of spoilage.It was high in Akara-Igboro because of the ingredient used to fry the cassava (Palm oil).

Table 3. Anti-Nutrient Composition (mg/100g) of the Traditional Diets

\begin{tabular}{|c|c|c|c|}
\hline Anti-nutrient & Akidi & Ofeachara & Akara-Igboro \\
\hline Phytate & $0.37 \pm 0.01^{\mathrm{a}}$ & $0.35 \pm 0.01^{\mathrm{a}}$ & $0.40 \pm 0.01^{\mathrm{b}}$ \\
\hline Alkaloid & $45.13 \pm 0.89^{\mathrm{b}}$ & $40.71 \pm 0.88^{\mathrm{a}}$ & $50.00 \pm 1.33^{\mathrm{c}}$ \\
\hline Tannin & $12.21 \pm 0.03^{\mathrm{c}}$ & $7.78 \pm 0.05^{\mathrm{b}}$ & $5.81 \pm 0.05^{\mathrm{a}}$ \\
\hline Saponin & $17.56 \pm 0.06^{\mathrm{b}}$ & $19.17 \pm 0.17^{\mathrm{c}}$ & $14.68 \pm 0.18^{\mathrm{a}}$ \\
\hline Oxalate & $9.24 \pm 0.44^{\mathrm{a}}$ & $11.88 \pm 0.44^{\mathrm{b}}$ & $27.28 \pm 0.88^{\mathrm{c}}$ \\
\hline $\begin{array}{c}\text { Cyanogenic } \\
\text { Gycoside }\end{array}$ & $0.87 \pm 0.11^{\mathrm{a}}$ & $1.17 \pm 0.10^{\mathrm{b}}$ & $1.62 \pm 0.12^{\mathrm{c}}$ \\
\hline
\end{tabular}

Values are presented as mean \pm S.D of triplicate determinations. Values on the same row with different superscript letters differ significantly.

Anti-nutritional factors are compounds inherent in plants which specifically help to decrease nutrient absorption [25].These anti-nutrients commonly regarded as plants secondary metabolites have been lauded to be active biologically [26]. Some of them are useful in nutrition and pharmaceuticals industries while a variety still elicit very harmful biological responses [27].

The phytate constituent of the traditional diets was high in Akara-Igboro $(0.40 \mathrm{mg} / 100 \mathrm{~g})$ followed by Akidi $(0.37 \mathrm{mg} / 100 \mathrm{~g})$ and low in Ofeachara mixed with Mgbam and Garri $(0.35 \mathrm{mg} / 100 \mathrm{~g})$. However, the value is comparably lower than those of some dishes such as potato Kuba $(9252 \mathrm{mg} / 100 \mathrm{~g})$, Lentil soup $(207 \mathrm{mg} / 100 \mathrm{~g})$ and falafel $(1355 \mathrm{mg} / 100 \mathrm{~g})$ [28].The high content of Akara-Igboro may be attributed to the presence of cassava, which is the major ingredient utilized in the preparation of the diets is famous for the high phytate content inherent in it. Akindahunsi and Oyetayo [29] reported that phytate concentration of Pleurotus tuber-regius maize for some hours before grinding. Perias and Gibson [30] reported that soaking cereal in water for sometime may likely lead to inert diffusion of some water soluble phytate, $\mathrm{K}, \mathrm{Na}$ and $\mathrm{Mg}$ which can be detached by pouring the water. There may also be the effect of thermal processing. Phytic produce covalent complexes with mineral ions in so doing renders them unavailable for gastro-intestinal absorption [31] thus inducing deficiencies. The Saponin contents of the cooked samples was high in Ofeachara mixed with Mgbam and Garri $(19.17 \mathrm{mg} / 100 \mathrm{~g}$ ), followed by Akidi $917.56 \mathrm{mg} / 100)$ but was low in Akara-Igboro $(14.68 \mathrm{mg} / 100 \mathrm{~g})$. The saponin content of the samples were considerably high when compared with the work of Sezgin and Artik [32] on fourteen individual samples of Turkish Tahini Halvah that ranged from $3.20 \mathrm{mg} / 100 \mathrm{~g}$ to $17.20 \mathrm{mg} / 100 \mathrm{~g}$. The decrease in the saponin content of the cooked sample was significant $(p<0.05)$ in Akara Igboro. This can be attributed to the effect of an incorporated approach that mixes a diversity of traditional food preparation and processing practices [33] such as thermal processing plus household pounding in the case of Akara-Igboro. The advantageous effects of saponins are mainly due to their anti-hypercholesterolemic activity [27]. Johnson [34] reported that saponin facilitates the uptake of materials from the gastrointestinal tract by increasing the permeability of mucosal cells in the intestine. Saponins pass through the body without causing deleterious effects because the body absorb them poorly [32] while Alkaloid was highest in Akara-Igboro $(50.00 \mathrm{mg} / 100 \mathrm{~g}$ ) and lowest in Ofeachara mixed with Mgbam and Garri $(40.71 \mathrm{mg} / 100 \mathrm{~g})$. The tannin content of the cooked samples of Akidi was $12.21 \mathrm{mg} / 100 \mathrm{~g}$, Ofeachara mixed with Mgbam and Garri $(7.78 \mathrm{mg} / 100 \mathrm{~g})$ and lowest in Akara-Igboro $(5.81 \mathrm{mg} / 100 \mathrm{~g})$. In comparison to those of sweet potatoes diets consumed in Kwara State they values obtained were quite high, it ranged from $0.22 \mathrm{mg} / 100 \mathrm{~g}$ to $0.86 \mathrm{mg} / 100 \mathrm{~g}$ [20]. Tannins are reported to have possible anticarcinogenic effect [35]. Dietary tannins helps to decrease the injurious potentials of internal parasites in sheep thus improving the health of animals [36].

The Cyanogenic glycosides contents of the cooked samples was high in Akara-Igboro $(1.62 \mathrm{mg} / 100 \mathrm{~g})$ followed by Ofeachara mixed with Mgbam and Garri $(1.17 \mathrm{mg} / 100 \mathrm{~g})$ but was low in Akidi $(0.87 \mathrm{mg} / 100 \mathrm{~g})$. The Cyanogenic Glycosides composition of the samples was high in comparison to those of beniseed soup cooked for 15, 30,45 and 60 minutes that range from $0.58 \mathrm{mg} / 100 \mathrm{~g}$ to $0.97 \mathrm{mg} / 100 \mathrm{~g}$ [37].The high content of cyanogenic glycoside found in akara Igboro and Ofeachara mixed with Mgbam and Garri was attributed to the basic ingredients cassava which was used in both diets. High dose of HCN can pose a serious inhibitory effect on the respiratory cytochrome oxidase activity [38].The oxalate content was high in Akara igboro $(27.28 \mathrm{mg} / 100 \mathrm{~g})$ followed by Ofeachara mixed with Mgbam and Garri $(11.88 \mathrm{mg} / 100 \mathrm{~g})$ but was low in Akidi $(9.24 \mathrm{mg} / 100 \mathrm{~g})$. The oxalate content of the samples was low compared to those of some sweet potato dishes consumed in Kwara State, Nigeria that ranged between $126.93 \mathrm{mg} / 100 \mathrm{~g}$ and $171.93 \mathrm{mg} / 100 \mathrm{~g}$ [20]. Oxalate is of great interest, because elevated concentrations of oxalate diets can enhance the possibility of renal calcium absorption [25]. 
Table 4. Vitamin Content $(\mathrm{mg} / 100 \mathrm{~g})$ of the Traditional Diets

\begin{tabular}{|c|c|c|c|}
\hline Vitamins & Akidi & Ofeachara & Akara-igboro \\
\hline Vitamin $\mathrm{A}$ & $17.97 \pm 0.01^{\mathrm{a}}$ & ND & ND \\
\hline vitamin $\mathrm{B}_{1}$ & $4.08 \pm 0.01^{\mathrm{b}}$ & $6.00 \pm 0.59^{\mathrm{c}}$ & $0.83 \pm 0.01^{\mathrm{a}}$ \\
\hline${\text { Vitamin } \mathrm{B}_{2}}^{\mathrm{a}}$ & $8.68 \pm 0.02^{\mathrm{a}}$ & ND & $21.67 \pm 0.02^{\mathrm{b}}$ \\
\hline Vitamin $\mathrm{C}$ & $\mathrm{ND}$ & $14.62 \pm 0.04^{\mathrm{b}}$ & $12.01 \pm 0.01^{\mathrm{a}}$ \\
\hline Vitamin $\mathrm{E}$ & ND & $0.08 \pm 0.07^{\mathrm{a}}$ & ND \\
\hline
\end{tabular}

Values are presented as mean \pm S.D of triplicate determinations. Values on the same row with different superscript letters differ significantly at $\mathrm{p} \leq 0.05 . \mathrm{ND}=$ Not detected.

Vitamins are indispensable natural substances that are required in minute concentrations in the diets for normal functioning of the body, growth and maintenance of body tissue ${ }^{39}$.The vitamin of the food samples studied shows that the entire food sample contained an appreciable quantity of both water and fat soluble vitamins. Generally, vitamins $B_{2}$ and $C$ has been seen to have the highest concentration in samples. This is attributed to their nature because they are soluble in water and as such not lost by most method of cooking such as boiling, steaming or soaking [40].

Vitamin A which was detected only in "Akidi" makes it an important diet in preventing dim light vision. While vitamin E, was detected only in "Ofeachara mixed with Mgbam and Garri”.

Table 5. Mineral Content (mg/100g) of the Traditional Diets

\begin{tabular}{|c|c|c|c|}
\hline Mineral & Akidi & Ofeachara & Akara-Igboro \\
\hline Copper & $0.11 \pm 0.00^{\mathrm{b}}$ & $0.08 \pm 0.01^{\mathrm{a}}$ & $0.08 \pm 0.00^{\mathrm{a}}$ \\
\hline Zinc & $0.97 \pm 0.36^{\mathrm{a}}$ & $0.72 \pm 0.57^{\mathrm{a}}$ & $0.70 \pm 0.02^{\mathrm{a}}$ \\
\hline Lead & ND & $0.16 \pm 0.15^{\mathrm{a}}$ & ND \\
\hline Calcium & $7.92 \pm 1.09^{\mathrm{a}}$ & $49.03 \pm 2.45^{\mathrm{c}}$ & $12.44 \pm 1.78^{\mathrm{b}}$ \\
\hline Iron & $5.62 \pm 0.71^{\mathrm{c}}$ & $4.14 \pm 0.46^{\mathrm{b}}$ & $1.11 \pm 0.37^{\mathrm{a}}$ \\
\hline Potassium & $4.49 \pm 0.06^{\mathrm{a}}$ & $9.13 \pm 0.17^{\mathrm{b}}$ & $9.16 \pm 0.24^{\mathrm{b}}$ \\
\hline Sodium & $1.03 \pm 0.01^{\mathrm{b}}$ & $1.06 \pm 0.07^{\mathrm{b}}$ & $0.94 \pm 0.07^{\mathrm{a}}$ \\
\hline Cadmium & ND & ND & ND \\
\hline
\end{tabular}

Values are presented as mean \pm SD of triplicate determinations. Values on the same row with different superscript letters differ significantly at $\mathrm{p} \leq 0.05$.

$\mathrm{ND}=$ Not detected.

Table 6. $\mathrm{Na} / \mathrm{K}$ Ratio of the Traditional Diets

\begin{tabular}{|c|c|c|c|}
\hline & Akidi & Ofeachara & Akara-Igboro \\
\hline $\mathrm{Na} / \mathrm{K}$ & 0.2 & 0.11 & 0.10 \\
\hline
\end{tabular}

Numerous dietary studies have demonstrated that multiple micronutrients deficiencies are prevalent in developing countries and have implicated poor availability of micronutrients and perhaps low dietary intake for the high pervasiveness of these multiple deficiencies [41]. This study reports the mineral composition of some selected aboriginal foods from Abia State. The metabolic roles of minerals and the amounts of them in the body vary considerably [39].
Sodium content of the traditional foods $1.06 \mathrm{mg} / 100 \mathrm{~g}$ in Ofeachara mixed with Mgbam and Garri to $0.94 \mathrm{mg} / 100 \mathrm{~g}$ in Akara-Igboro.The sodium content may be attributed to the table salt used in the preparation of the traditional foods. The sodium content of the foods in the present work is considered low compared to Ikwerre traditional foods in which sodium ranged from 3.61 to $3.48 \mathrm{mg} / 100 \mathrm{~g}$ [15]. Sodium is a key factor in retaining body water and the most important positive ion in the extracellular fluid. Elevated concentration of sodium in the body has been implicated in hypertension which results to increased loss of calcium in urine [39].

Potassium content of the diets ranged from $9.13 \mathrm{mg} / 100 \mathrm{~g}$ in "Ofeachara mixed with Mgbam and Garri" to $4.49 \mathrm{mg} / 100 \mathrm{~g}$ in Akidi. These values were normal compared to those reported in some Cameroonian household food which ranged from $197.33 \mathrm{ppm}$ to $134.3 / 100 \mathrm{~g}$.In the biological system, potassium also plays an analogous role with sodium but it is connected with lower blood pressure [39]. It helps the body to maintain acid base regulation and osmotic pressure [1]. Deficiency could lead to muscle cramps, irregular heartbeat and loss of appetite. For the preclusion of blood pressure in the body, sustaining the $\mathrm{Na} / \mathrm{k}$ ratio in the body is sacrosanct and a ratio $<1$ is recommended [42].The $\mathrm{Na} / \mathrm{k}$ of the 3 diets is less than one, hence the food samples are considered adequate in reducing the incidence of high blood pressure.

The calcium content of the traditional foods ranged from $49.03 \mathrm{mg} / 100 \mathrm{~g}$ in Ofeachara mixed with Mgbam and Garri to $7.92 \mathrm{mg} / 100 \mathrm{~g}$ in Akidi. The high level of calcium in "Ofeachara mixed with Mgbam and Garri" may be attributed to the stockfish and the vegetable "Achara" used during the preparation of the foods. Ogbonna [43] observed increase in calcium, potassium and phosphorous levels when African yam bean was fermented for the preparation of condiment. The values are high compared to those of sweet potato dishes consumed in Kwara State, Nigeria that ranged between $19.99 \mathrm{mg} / 100 \mathrm{~g}$ and $27.99 \mathrm{mg} / 100 \mathrm{~g}$ [44]. Calcium is the most abundant mineral in the body with $99 \%$ of calcium enclosed inside teeth and bones [39]. According to Allen [44] a deficiency of calcium in the body has been implicated in osteoporosis. The iron contents of the diets ranged from $5.62 \mathrm{mg} / 100 \mathrm{~g}$ in "Akidi" to $1.11 \mathrm{mg} / 100 \mathrm{~g}$ in "Akara-Igboro" which were almost similar in comparison to those reported by Amadi [15] on some traditional diets of Southern Nigeria that ranged from $0.21 \mathrm{ppm}$ to $6.03 \mathrm{mg} / 100 \mathrm{~g}$. The recommended daily allowance for iron is $10 \mathrm{mg} /$ day and $15 \mathrm{mg}$ /day for men and women respectively which suggest that the selected food can meet the daily dietary requirements for iron [39].This concurs to previous reports that most indigenous foods in Nigeria are rich in iron [45]. Iron deficiency is highly prevalent in most developing countries [46].

The copper contents of the traditional food samples ranged from $0.08 \mathrm{mg} / 100 \mathrm{~g}$ in "Ofeachara mixed with 
Mgbam and Garri" and "Akara-Igboro" respectively to $0.11 \mathrm{mg} / 100 \mathrm{~g}$ in "Akidi". The suitable limit for copper consumption for human is $10 \mathrm{ppm}$. Copper levels were low when compared to those recorded in Ikwerre traditional foods [15]. The entire food sample examined had their copper contents below the maximum acceptable limit of $2.00 \mathrm{ppm}$ set by WHO. Copper is an indispensable nutrient that plays a vital role in the human body by performing as a ligand to numerous enzymes and proteins [47].

The zinc content of the traditional food samples ranged from $0.70 \mathrm{mg} / 100 \mathrm{~g}$ in "Akidi". The tolerable limit for human consumption of zinc is $150 \mathrm{ppm}$ [48]. Zinc contents were higher when compared to those recorded in Ikwerre traditional foods [15]. The results got for $\mathrm{Zn}$ in the food samples were below the maximum tolerable limit of $3.00 \mathrm{ppm}$ documented by WHO but they are within the normal range of $0.1-3.0 \mathrm{ppm}$ for vegetables and fruits. Zinc is an indispensable trace element in the body; it supports normal development and growth during childhood and pregnancy [49]. High levels of zinc and copper cause diarrhea, depressed immune function, impairment of growth and reproduction [50]. According to WHO [51] report deficiency of zinc and copper occur especially due to reduced dietary intake or due to decreased availability from foods.

The lead content of the food samples was $0.16 \mathrm{mg} / 100 \mathrm{~g}$ in "Ofeachara mixed with Mgbam and Garri" but was not detected in "Akidi" and "Akara-Igboro". The concentration of lead was within the tolerable limit of $0.1 \mathrm{mg} / 100 \mathrm{~g}$ [52].Lead enters the human body via food, water and air and is not easily removed by washing vegetables and fruits [53].

\section{Conclusions}

The nutrient constituents of the traditional foods (Akidi, Akara-Igboro and Ofe-Achara mixed with Mgbam and Garri) suggest that they are rich sources of indispensable nutrients. Consequently, they may make significant contributions to consumptions of fibre, proteins, carbohydrates as well as some minerals and vitamins. However, the presence of anti-nutrients may possibly affect the exploitation of some of the micronutrients present in the diets. On the other hand, Ofeachara mixed with Mgbam and Garri was more preferable in the overall acceptability of the three traditional foods.

\section{Acknowledgements}

The authors received no external funding for this study.

\section{Conflict of Interest}

The authors declare that there is no conflict of interests regarding this article.

\section{REFERENCES}

[1] Olusanya, J.0. (2008). Essentials of food and nutrition .1 edition, Apex books limited, Lagos.

[2] Wahlqvist, M.L. (2011). Food and Nutrition: Food and /health Systems in Australia and New Zealand ( $3^{\text {rd }}$ ed.). NSW, Australia: Allen \& Unwin. Pp.429-441.ISBN 978-1-74175- 897-9.

[3] Trichopoulou, A., Soukara, S., and Vasilopoulou, E., "Traditional foods: a science and society perspective," Trends in Food Science \& Technology, 18 (8). 420-427. 2007.

[4] Benjamin AA, Eugene NO, Edward OA. Fatty and amino acid composition of "Onunu" and "Mgbam", traditional diets of the Ikwerre people of Nigeria. Continental J Food Science and Technology. 2011; 5(1):37-45.

[5] Duru M. Amadi B, Agomuo E, Eze A. Chemical profile of an anti-malarial concoction "Udu" used in Umunchi autonomous community in Isiala Mbano LG. A of Imo State, Nigeria. JETEAS. 2012; 3(3):444-437.

[6] Amadi Benjamin, Duru Majesty, Agomuo Emmanuel, Amadi Peter and Onedibe Ozioma. (2017). Nutritional, Phytochemical and Sensory Evaluation of "Mberiagworagwo" Traditional Food of Uruagunnewi People in Anambra State, Nigeria. Journal of Advances in Biology \& Biotechnology, 14(1): 1-8

[7] Musaiger, A.O., Al-Jedah, J.H., D'Souza, R., "Nutritional profile of ready-to-eat foods consumed in Bahrain," Ecology of Food and Nutrition, 46 (1). 47-60. 2007.

[8] ElObeid, T., Phoboo, S. and Magdad, Z., "Proximate and Mineral Composition of Indigenous Qatari Dishes: Comparative Study with Similar Middle Eastern Dishes," Journal of Food Chemistry and Nutrition, 3 (1). 27-34. 2015.

[9] Onwuka GI. Food analysis and instrumentation theory and practice, $1^{\text {st }}$ edition, Naphthali prints, Surulere, Lagos. 2005; 140.

[10] Amadi BA, Agomuo EN, Ibegbulem CO. Research methods in Biochemistry, Supreme Publishers, Owerri, Imo State, Nigeria. 2004; 66-69.

[11] A.O.A.C (1990). Official Methods of Analysis Association of Official Analytical Chemists. Washington D. C. $15^{\text {th }} \mathrm{Ed}$ Section 968.08 .

[12] Balagopalan, C., Padmaja. G., Nanda, SK., and Moorthy, S.N. (1988). Cassava in food, feed and industry. CRC PressInc, Florida.

[13] Harbone, J.B., (1973). Text Book of Phytochemical Methods. $1^{\text {st }}$ Edition, Champraan and Hall Ltd. London: 110-113.

[14] Ibanoglu S, Ainsworth P, Wilson G and Hayes G.D, (1995). The effect of Fermentation Conditions on the Nutrients and 
acceptability of Tarhana. Food Chemistry J3(2): 143-147.

[15] Amadi, B.A., Onyeike, E.N. and Ayalogu, E.A. (2012). Mineral content and Sensory Evaluation of "Onunu" and "Mgbam", Traditional Diets of Ikwerre People of Nigeria Archive of Applied Science and Research. 4(1):330-335.

[16] Musaiger, A.O., Al-Mohizea, I. S., Al-Kanhal, M.A. and Iaidah, J.H. (1990). Chemical and Amino Acid Composition of Four Traditional Foods Consumed in the Arab Gulf States. Food. Chem. 36:181-189.

[17] Umoh, I.B. (1992). Changes in the Nutrition Values of some Nigerian Diets after Cooking by Certain South-Eastern Traditional Methods. Ph.D. thesis, University of Ibadan.

[18] Onyeike, E.N., Ayalogu, E.0. and Uzogara, S.G. (1995). Inluence of heat Processing of African Yam Bean Seed (sphenostylis stenocarpa) Flour on the growth and organ weights of rats. Plant Foods for Human Nutrition 48:85- 93.

[19] Kpikpi, E.N., Dzogbefia, V. and Glover, R.K. (2009). Enzymatic and some Biochemical Changes Associated with the Production of "Kantong", a Traditional Fermented Condiment in Northern Ghana. Journal of Food Chemistry. 33(1):61-73.

[20] Abubakar, H. N., Olayiwoka I. O., Sanni S. A and Wowu, M. A (2010). Chemical Composition of Sweet Potato (Ipomea Batatas lam) Dishes as Consumed in Kwara State. Nigeria. International Food Research Journal 19:411-416.

[21] Das, P., Devi, L.P. and Gogoi, M. (2009). Nutrient Composition of some Regional recipes of Assam, India. Ethno-Med. 3(2):111-117.85

[22] Saldanha, J.O. (1995). Fibre in the diet of U.S Children: Result of National Surveys. Pediatrics 96:994-996.

[23] Olusanya J.0. (1991). The Nutrient Composition of all Vegetable based Snacks. Nigeria Journal of Nutrition 12(1):18-19.

[24] Achinewhu, S.C. (1998). Nuts and Seed. In: Nutritional Quality of Plant Food (ed.) by Osagie, A.U and Eka, 0. U.). $15^{\text {th }}$ Edition Post Harvest Research Unit, University of Benin, Benin city, 134-159.

[25] Osagie, A. U., Muzquiz, M., Burbano, C.O., Cuadrado, C., Ayet, G. and Castano, A. (1996).Some Antinutritional Constituents in ten Staple Food Items Grown in Nigeria Tropical Sci. 36: 109-115.

[26] Zank, H.M. (1951). Chasing the Enzymes of Secondary Metabolism: Plant Cell Cultures as a Point of Goal. Phytochemistry, 309(12):3861-3863.

[27] Oakenfull, D.G. and Sidhu, G.S. (1989). Saponins. In Toxicants of Plants Origin Glycosides, Eiby P.R. Cheeke. C.R.C. Press. Inc. Lorida 4.9-115

[28] Dashti, B.H., AL.Awadi, F., Khalafawi, U.S., AL.Zeki, S and Sawaya, W. (2011) Nutrient Contents of some Traditional Kuwaiti Dishes: Proximate Composition and Phytate Content. Food Chemistry. 74:169-175

[29] Akindahunsi, A.A. and Oyetayo, F.L. (2006). Nutrient and Antinutrient Distribution of ediblie Mushroom, Pleurotus tuber- Regium (fries) singer. L.W.T., 39:543-553.

[30] Perias, L. and Gibson, K.S. (2002). Use of Soaking to Enhance the Bioavailability of Iron and Zinc from
Rice-Based Complementary Foods used in the Philipines. Journal of Food Agriculture, 82:1115-1121.

[31] Lopez, H.W., Leecherdt, F. Coudrat, C. and Kesmesy, C. (2002). Minerals and Phytic Acid Interactions: is it a Real Problem for Human Nutrition? International Journal of Food Sciences and Technology 37:723-739.

[32] Sezgin, A.EC. and Artik, N. (2010). Determination of saponin content in Turkish Tahni Halvah by using HPLC. Advanced Journal of Food Science Technology. 2(2):109-115.

[33] Hotz, C. and Gibson, R.S. (2007). Traditional foods Processing and Preparation Practices to Enhance the Bioavailability of Micronutrients in Plant-based Diets. Journal of Nutrition. 137:1077-1100.

[34] Johnson, I.T., Price, K., and Fenwick, G.R. (1986). Influence of Saponin on gut Permeability and Active Nutrient Transport in vitro. 116:2270-2279.

[35] Butler, L.G. (1989). Effects of Condensed Tannin on Animal Nutrition. In: Chemistry and Significance of Condensed Tannins. R.W. Hemingway and J.T. Karchery Eds. Plenum Press New York Pp. 391-402.

[36] Niezen, I.H., Waghorn,, T.S., and Waghorn, G.C. (1995). Growth and Gastrointestinal Nematode Parasitism in Lambs Grazing either Lucerne (Medicago sativa) or Sula (Hedysarum Coronarium) which Contains Condensed Tannins. Journal of Agricultural Science. (cam) 125: 281-289.

[37] Agiang, M.A., Umoh, 1.B., Essien, A.I. Eteng, M.U. (2010). Nutrient Changes and Antinutrient Contents of Beniseed Soup During Cooking using a Nigerian Traditional Method. Pakistan Journal of Biological Study. 13:1011-1015.

[38] Onigbinde, A.O. (2005). Food and Human Nutrition (Biochemical Integration). Education Advanced Corporate organization Limited: Benin City.

[39] Wardlaw, G.N., (1997).Encyclopedia of Food Technology and Nutrition (R.Macrae-, R.K Robinson, M.J. Sadler, eds). Academic Press, London, 1237-1243.

[40] Allan G., Cameron B., Yvonne Lilymare (1982). "The Science of Food and Cooking: Tropical Edition, Edward Anode Publishers Ltd., GB.

[41] Mueller I. (2001). Analysis of Hydrolysable Tannins. Animal Feed Study Technology 91:3-20.

[42] Olaofe, O., Faleye, F.J., Adeniji, A.A. and Akinsola, A.F. (2009). Amino Acid, Mineral Composition and Proximate Analysis of Chinese Bottle, Lagenaria Sciceraria. 8(7):534-543.

[43] Ogbonna D.N, Sokari T.G, and Achinewhu S.C. (2001) Development of an Owoh-Type Product from African yam beans (Spherostylis Stenocarpa) Hoechst ex. A Rich Harms by Solid Substrate Fermentation. Plant foods and Human. Nutrition. 56: 183-194.

[44] Allen, L.H. (2001). Micronutrients. 2020 focus 5 (Health and Nutrition Emerging and Re- Emerging issues in Developing Countries). Brief 10 of, February, 2011.

[45] Latunde - Dada, G., (1997). Sources and forms of iron in Nigerian Foods and effects of processing on availability. 
Food Nutrition. Bull, 18: 84-89.

[46] Openheimer, S.J., (2000).Iron and its Relation to Immunity and Infections Disease. Journal of Nutrition, 131: $6165-$ 6335 .

[47] Wu, J., M. Ricker and J. Muench (2006).Copper Deficiency as a cause of Unexplained Hematologic and Neurologic Deficits in Patients with Prior Gastrointestinal Surgery J. Am. Board of Family Med., 19:194.

[48] Nair, M., K.K. Balachandran, V.N., Sankarnarayan and T. Joseph (1997).Heavy Metals in Fishes from Coastal Waters of Cochin, South West Coast of India. Indian Journal of Marine Science., 26: 98-100.

[49] Simmer, K. and R.P. Thompson, (1985). Zinc in the Foetus and Newborn. Journal of Health Professional Fact Sheet
(National Institute of Health), 319:158-163.

[50] Gordon, M.W., (1985). Contemporary Nutrient Issues and Insights. McGraw- Hill Higher Education, New York.

[51] WHO (2003). World Health Organization. Technical Report Series No. 532, 9-19.

[52] ACGIH (American Conference of Government Industrial Hygienists). (2004). Lead Threshold Limit Values for Chemical Substances and Physical Agents and Biological Exposure Indices. (Incinnati, $\mathrm{OH}$ ).

[53] Divrikli U, Saracoglu Su, and Soylak M. (2003). Determination of Trace Heavy Metal contents of Green Vegetables samples from Kayseri-Turkey by Flame Atomic Absorption Spectrometry. Fresenius Environment. Bull. 121:1123-1125. 